\title{
GENOGRAM AND ECO-MAP AS TOOLS FOR UNDERSTANDING FAMILY CARE IN CHRONIC ILLNESS OF THE YOUNG ${ }^{1}$
}

\author{
Ítala Paris de Souza², Roseney Bellato ${ }^{3}$, Laura Filomena Santos de Araújo ${ }^{4}$, Karla Beatriz Barros de Almeida ${ }^{5}$
}

${ }^{1}$ Text extracted from matrix research - A instituição jurídica como mediadora na efetivação do direito pátrio à saúde: análise de itinerários
terapêuticos de usuários/famílias no SUS/MT, sponsored by the Notice of Research Support of Universidade Federal do Mato Grosso
(UFMT), with a grant from the Fundação de Amparo à Pesquisa do Estado do Mato Grosso.
${ }^{2}$ M.Sc. in Nursing, Programa de Pós-Graduação em Enfermagem, UFMT. CAPES Scholarship. Cuiabá, Mato Grosso, Brazil. E-mail:
italaparis@hotmail.com
${ }^{3}$ Ph.D. in Nursing. Professor, Faculdade de Enfermagem, UFMT. Cuiabá, Mato Grosso, Brazil. E-mail: roseneybellato@gmail.com
${ }^{4}$ Ph.D. in Nursing. Professor, Faculdade de Enfermagem, UFMT. Cuiabá, Mato Grosso, Brazil. E-mail: laurafil1@yahoo.com.br
${ }^{5}$ Doctoral student, Programa de Pós-Graduação em Enfermagem, UFMT. Cuiabá, Mato Grosso, Brazil. E-mail: karlinha_bba@hotmail.com

\begin{abstract}
The aim of this study was to understand family organization in care nucleus and supporting networks for families of young patients who experienced childhood kidney disease and adolescent cancer. It is a situational study using the history of life by means of in-depth interviews and observation. A genogram and an eco-map were used as analytical tools for data organization and analysis. The genogram showed family composition and the relationships established among its members and the care nucleus, strengthening the continuing and prolonged care required by the youth. The eco-map contrasted the punctual and unlinked work of the supporting network with the implicated, affective, and continuing work from the base network participation in the illness experienced by the youth. These tools allow health professionals to know the family organization in care, and the resources and networks with which they count on for support through the experience of a chronic illness.
\end{abstract}

DESCRIPTORS: Adolescent. Family. Right to health. Chronic disease.

\section{GENOGRAMA E ECOMAPA COMO FERRAMENTAS PARA COMPREENSÃO DO CUIDADO FAMILIAR NO ADOECIMENTO CRÔNICO DE JOVEM}

RESUMO: Este estudo objetivou compreender a organização familiar em núcleos de cuidado e redes de sustentação e apoio tecidas por família de jovem que vivenciaram, na infância, doença renal e, na adolescência, o câncer. Estudo de situação, utilizando história de vida, operacionalizada por entrevista em profundidade e observação. Para organização e análise dos dados, empregou-se as ferramentas analíticas genograma e ecomapa. O genograma mostrou a composição familiar e as relações estabelecidas entre seus entes e os núcleos de cuidado, potencializando o cuidado continuado e prolongado exigido pelo jovem. O ecomapa contrastou a atuação pontual e desvinculada da rede de apoio com a forma implicada, afetiva e continuada com que a rede de sustentação participou da experiência de adoecimento do jovem. Tais ferramentas permitem aos profissionais da saúde conhecer a organização familiar para o cuidado, os recursos e redes com que conta para sustentá-la e ampará-la na experiência de adoecimento crônico.

DESCRITORES: Adolescente. Família. Direito à saúde. Doença crônica.

\section{GENOGRAMA Y ECOMAPA COMO HERRAMIENTAS PARA COMPRENSIÓN DEL CUIDADO FAMILIAR EN LAS ENFERMEDADES CRÓNICAS DEL JOVEN}

\begin{abstract}
RESUMEN: El objetivo de este estudio es comprender la organización familiar en núcleos de cuidado y las redes de sustentación y apoyo tejidas por familias de jóvenes que vivieron, en su infancia, enfermedad renal y, en la adolescencia, el cáncer. Estudio de Situación, utilizando la Historia de Vida, operada por la Entrevista en Profundidad y Observación. Para organización y análisis de los datos, empleamos las herramientas analíticas genograma y el ecomapa. El genograma mostró la composición familiar y las relaciones establecidas entre sus entes y los núcleos de cuidado, potencializando el cuidado continuado y prolongado exigido por el joven. El ecomapa contrastó la actuación puntual y desvinculada de la red de apoyo con la forma implicada, afectiva y continuada con que la red de sustentación participó de la experiencia de la enfermedad del joven. Tales herramientas permiten a los profesionales de la salud conocer la organización familiar para el cuidado, los recursos y redes con que cuenta para sustentarla y ampararla en la experiencia de enfermedades crónicas.
\end{abstract}

DESCRIPTORES: Adolescente. Familia. Derecho a la salud. Enfermedad crónica. 


\section{INTRODUCTION}

Diseases that are experienced by individuals and families can take several configurations, one of them being the chronic state that frequently involves the long-term disease process that integrates the context of life of several family members, with specific meanings being assigned to the experience of caring for each of these members. ${ }^{1}$ This experience can bring about permanent repercussions throughout life, particularly in the social, personal and family dimensions, raising uncertainties and changes in daily life. ${ }^{2}$

Regarding chronic diseases in adolescents, the World Health Organization, in the document 'The adolescent with a chronic condition', reveals a significant increase in developed and developing countries, with an estimate that, in 2020, it will be the leading cause of death in this population, becoming a serious public health problem. ${ }^{3}$ Considering that this stage of life is marked by significant physical, social and individual changes, and that the establishment of a chronic disease intensifies this experience, care and support at such a singular stage will be a major challenge, especially for the families. ${ }^{3}$ Studies consider that the experience of a chronic disease in the lives of young people and children affects daily life in many ways, especially for the family, who reorganizes itself, and prioritizes time in order to provide care for the members who need it. ${ }^{3-5}$

Living with a disease implies changing lifestyles, and developing coping strategies that make the ill person and his/her family establish a new relationship with life. ${ }^{6}$ Studies indicate that family involvement in the care since the disease onset, marked by daily treatment support, allow children and adolescents to mitigate the disease, and to develop improved ways for dealing with the situation. ${ }^{7-8}$

In line with this way of understanding the disease experience, this study adopts the perspective that the family is the primary caregiving unit that rearranges itself to try to search, produce and manage daily care throughout the experience of illness of one of its members. ${ }^{9}$ We also believe that in the search for care there is often great expenditure of effort due to ineffective responses offered by health services and professionals to their needs.

In this movement, the family creates networks involving people and close relations that can ensure its sustainability and support in their own care, as well as the obtainment of conditions and resources necessary for it. ${ }^{10}$ Explaining this movement allows us to understand the ways of coping, and the efforts and expenditures that fall on the family, which are more marked when the disease and care process are lasting and intense. The use of the genogram and eco-map, as tools that explain and analyze this experience, allows to see and understand the way a family organizes itself for care, as well as the search undertaken with the services and healthcare professionals, answers and their effectiveness.

Therefore, with the use of the genogram and eco-map as analytical tools, we aim to understand how the family of a young person with two concomitant chronic diseases, kidney disease since childhood and cancer, faces the disease and its implications, forming care nucleus, and creating support networks to help them through this process.

\section{METHOD}

This is a situational study, a term first coined in a paper, ${ }^{11}$ being subsequently appropriated by some authors, ${ }^{12-13}$ who conceptualize it as a singular way of close approaching of the researcher with the procedures and life contexts of the members of a family that experiences disease and care. They also emphasize that this approach allows researchers to understand and highlight the meanderings of the relations of various levels that are established, particularly those of intense emotional charge, specifically conforming and modulating each experience of illness and care.

The research participants were selected through a search in a reference cancer treatment institution of the Unified Health System in the state of Mato Grosso (SUS-MT), based on the following criteria: to be a SUS-MT user; to be experiencing a chronic disease resulting from cancer; to have experienced the disease during adolescence; to be a resident in the state of Mato Grosso. The concomitant occurrence of cancer and kidney disease was found after the study family was selected.

The subject selected was a 21-year-old boy, fictitiously named as Marco, resident in the countryside, who experienced the onset of concomitant diseases due to kidney disease since childhood, 
and cancer in adolescence. Using the approach of life history, an in-depth interview and observation $^{14}$ were conducted with the young man, his parents, Olavo and Rita, and his aunt, Lair, who also looked after him. Eleven interview meetings took place from March to May 2011 in the city of Cuiabá, Mato Grosso, where the family members who participated in Marco's disease experience lived; in City A where the boy lived with his family through the course of his disease, and also in City $\mathrm{B}$ where he was living at the time of the interview with two brothers and a cousin.

The recorded and fully transcribed narratives, along with the field observations, were organized in a research diary, in Microsoft Word ${ }^{\circledR}$ file format, totaling 224 pages, which was this study corpus of analysis.

The analysis procedure took place along with the fieldwork; however, after the first two interview meetings, since we already had an overview of family constitution and relationships, as well as its organization for care, the genogram and eco-map were manually drafted. In the next meeting, the draft was validated with the family, time when the remaining doubts were clarified. The meeting also provided an opportunity for the family to participate in the process of comprehension, formation and organization of the analysis, ${ }^{15}$ so the tools could express, as faithfully as possible, the movements of family reorganization for care.

Following the completion of fieldwork and transcription, we proceeded with an attentive reading of the analysis corpus seeking to identify relevant aspects of the narratives that could improve the designs, bringing dimensions that had not been visualized, in line with the experience of illness and lifetime care for Marco and his family. Corpus reading ${ }^{16}$ was the basis for the construction of a descriptive and analytical framework of family organization to the care in the disease experience, focusing on narratives that expressed the imbricated arrangements and rearrangements.

The interpretation of this framework, which was made simultaneously with the listed procedures, allowed an image representation of family organization and dynamics in their transgenerational conformation, along with the arrangements that were being made over time to face the disease and provide care. ${ }^{4}$ The nuclei of the young man's care were highlighted through the course of his disease experience, involving family members who participated more directly in each of them, and the eco-map composition, which contains the support networks that the family created to help them in this process. ${ }^{9}$ In correspondence with the movement of interpretation, the drawings of the genogram and eco-map were re-elaborated with Edraw Mindmap ${ }^{\circledR}$ software, which is specifically designed for typesetting and editing graphic designs, information flows, diagrams with colors, figures, shapes and styles.

The genogram allows to view the family structure, and to identify, especially for this study, the affective bonds. ${ }^{17-18}$ The ecomap allows the comprehension and imagetic visualization of relationships, bonds, and interactions ${ }^{19}$ among family members and out of the family.

The symbols used in the genogram ${ }^{20-21}$ and in the eco-map ${ }^{22}$ followed standardization referenced by the authors. Symbols that were elaborated with specific characteristics ${ }^{17,22}$ sought to represent, in this study, relationships, movements, institutions and/or persons of the study family, explaining singularities - e.g., the diamond, the blue star and the red star in the genogram (Figure 1) represent, respectively, distant, harmonious, strong and harmonious relationships.

The matrix research to which this study is an integral part was approved by the Etical Research Committee of Hospital Universitário Júlio Müller, as per protocol N. 671/CEP-HUJM/09. All ethical guidelines were followed regarding the people interviewed, as well as the institutions and healthcare professionals mentioned.

\section{RESULTS AND DISCUSSIONS}

Use of the genogram for specifying family composition and arrangements for care

Marco was born in a city located $210 \mathrm{~km}$ away from the city of Cuiabá, and lived in a small rural property, along with his brothers and parents, as shown in figure 1. 


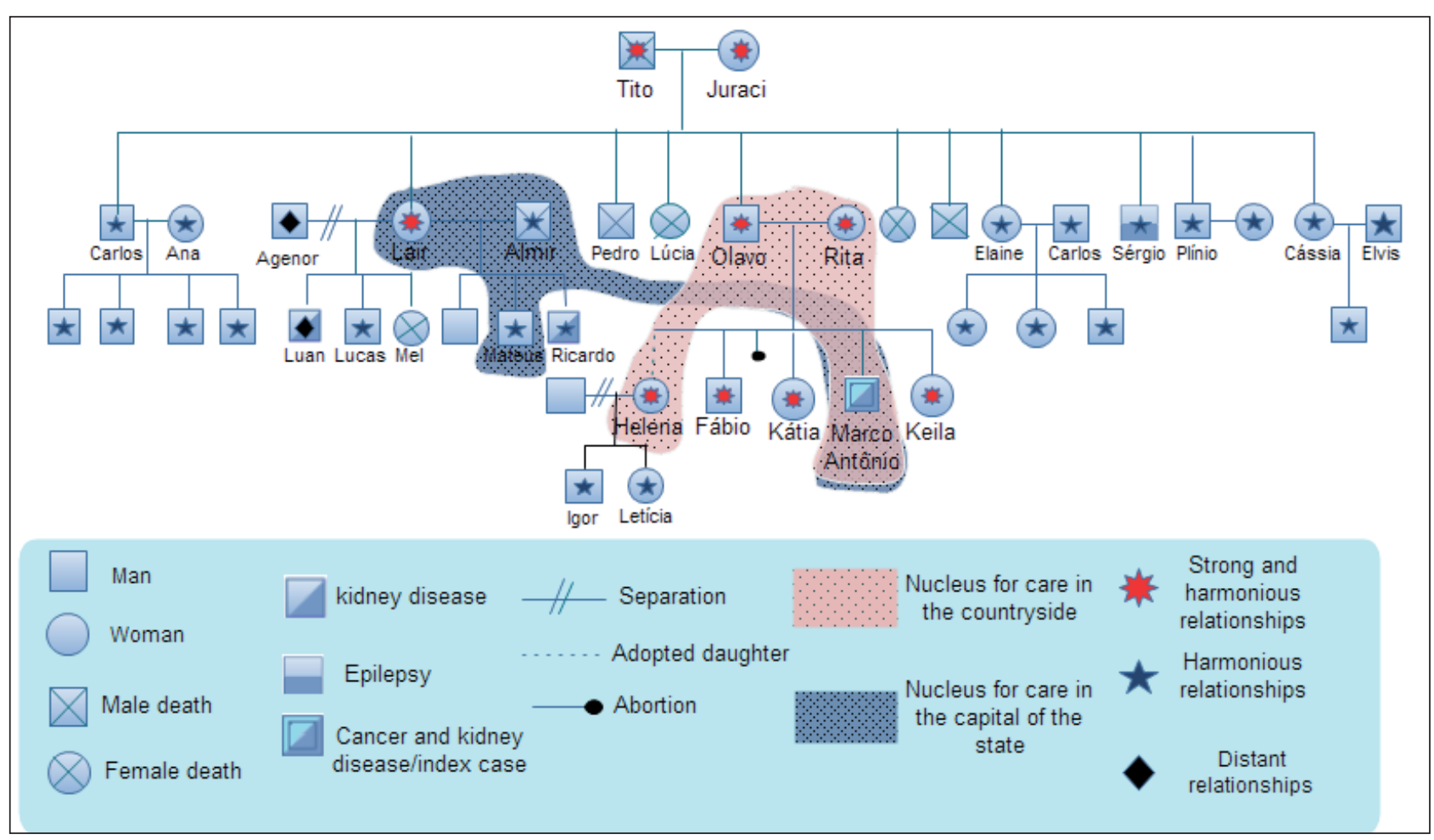

Figure 1 - Genogram of a young man who experienced concomitant chronic illnesses: kidney disease and cancer, and his family. Cuiabá-MT, 2015

The genogram (Figure 1) allows to view the expanded composition of the family in its transgenerational conformation, starting from the paternal grandparents of the young man, with the affective bonds the young man had with each family member being marked.

Having a singular way of living, we can observe the predominance of intense and harmonious bonds among the members of this family, an important aspect when we consider that the young man, since his birth, had serious health problems, requiring continuous and permanent care.

The first time parents searched for medical care, when the boy was three years old, he had constant pain, but the disease was not detected. The late diagnosis of ureteral stenosis occurred only when he was eight years of age, already presenting the development of unilateral hydronephrosis. Then, he underwent two kidney surgeries, one when he was eight, and another when he was fourteen years old. At this age, he began to feel pain in the ear, later being diagnosed as a malignant tumor in the right jaw, which forced the family to undertake many searches for professional care again.

Taking Marco's experience, and the implications that the chronic situation ${ }^{1}$ caused in his life and in his family's life, we corroborate the claim that the family is the main nucleus of care in the context of a disease. ${ }^{9}$ In this case, to face the intense burden of continuing and prolonged care required in the occurrence of concomitant diseases that shaped his experience, the parental family, who resided in a rural area in the state, had to mobilize family members who lived in the capital, and they welcomed and cared for him (figure 1).

This family arrangement for care, which we call care nucleus, ${ }^{23}$ became indispensable in his situation because of the many searches that the family made at services and with healthcare professionals, especially when he needed specialized treatment. This family organization mode in caregiving nuclei, including those geographically distant, allowed the young man to have prolonged care, albeit at the expense of physical and emotional energies of the various members in the family. ${ }^{24}$

To understand this family form of organization, it is necessary to analyze the extent of the bonds of consanguinity and intensity of relationships that link Marco's family, specified in Figure 1 in the form of symbols, and clearly described by the young man: when I was taking chemotherapy, aunt Lair was with me [...] I asked her to stay with me, then I came, arrived here [in Cuiabá] and she stayed with me, she stayed in the hospital with me for three days, and then we went home (Marco). 
The care nucleus in the capital consists mainly of Lair, her husband Almir and her son Mateus. These people are an important support for the young man, in his constant trips to Cuiabá during the specialized medical treatment. This family was also mobilized to help with his expenses, offering him the best comfort possible, even with limited material conditions: my God, that is my second home! [Referring to Lair's house] [...] They give me a lot of support! There, we are always welcome! [...] She helped a lot there, running after some tests too. The ones I couldn't search, she did it for me (Olavo).

There was evidence that Olavo and Lair were the ones who focused on Marco's health care, particularly in regard to many searches undertaken through health services and after professionals in the long period of the disease. In the case of Olavo, it was noticed that he was dedicated to this activity with much effort, being the most frequent presence in various services, both in Cuiabá and in the countryside: I went to Cuiabá [...] Even when there wasn't a car from the health service [Health Department] I went by bus. I left here and took the bus in the city and went by bus in the afternoon (Olavo). [...] When it wasn't me, it was his father, right? His father stayed two or three days, then he got tired, so I came ... he came to rest, right? Then I went to be with Marco (Lair).

As already pointed out, figure 1 allows to see that the affective relationships that Marco keeps with his family are very strong, especially with parents, siblings and his aunt Lair, also preserving harmonious relationships with all other members of their family. Since there was reciprocity in their affection, care could be shared in different ways among family members, something that greatly contributed for this care to be sustained through the young man's childhood and adolescence.

This affective proximity takes us to the author who says that when experiencing situations of disease in the family, each member strengthens his/her identity as a social group, overcoming weaknesses and vulnerabilities, reflecting feelings of solidarity that accentuate affective bonds. ${ }^{25}$ Moreover, the formation of different care nucleus leads us to relativize the idea that there is a major family caregiver; the genogram (Figure 1) shows the multiple arrangements of familiar members for care. ${ }^{2}$

It was assumed that the family is fundamental in care 'of', 'in', and 'for' life; i.e., it not only takes care to restore health, but above all, do it in a broad way. ${ }^{26}$ In the production of this care, each member offers a substrate in the expansion of their capabilities and possibilities, ${ }^{5}$ with these being changeable in time and space. Thus, it is important to highlight the care produced 'in' and 'for' the family, in different ways and places, either by the many family members, the ill person as personal care, or the shared care through networks that support and sustain the family, seeking to guarantee, to each member, the necessary substrate for the production of care. Therefore, it is understood that, to apprehend family care to Marco, it is necessary to understand the family arrangements and rearrangements that were so singularly produced so the best care could be offered to him.

The genogram allows us to visualize the family composition and, in it, the relationships that are established among the members, the care nucleus, but it does not allow us to highlight the other participants of this care at different times and in different ways. Due to the care required by Marco, that is continued and prolonged, the family produced networks of relations with their close ones, so as to enhance their care, keeping it through time. Thus, we used the eco-map to show these networks. ${ }^{9}$

\section{Use of the eco-map in the explanation of networks for care}

In the dynamic movement to cope with disease, the family creates specific networks that can give them support in the process of search, production and management of health care. ${ }^{10}$ This creation becomes even more intensified when the service organization and professional health practices show they are less resolutive, failing to provide the necessary support to the ill person and the family, beyond mere occasional intervention in the diagnosis and treatment of the disease.

To understand the context in which these networks were created, a brief description of Marco's family way of life at the time of his disease was presented.

The rural property where the young man and the family lived had simple houses where uncles, cousins, godparents and grandparents live. Next to this property, there is a community of approximately 720 people, where he and his brothers studied and established strong affective bonds with the local population, such as the school principal, teachers and friends of the religious community in the village.

The eco-map (Figure 2) shows the networks created by the family in Cuiabá and in Cities A and $\mathrm{B}$ in the countryside, as well as the rural com- 
munity in which he lived initially. In the center of the drawing, the family members who lived with Marco are represented, reinforcing these people as the center of care. Thick solid lines and double lines were used to designate the very strong bonds, the dense ones and single ones to the strong bonds and, as the strength of relationship bonds weakened, the line density decreased the same way, and this was called moderate, punctual or weak. The two circles filled with blue and carmine show, respectively, the sustenance networks, and the support networks created by the family.

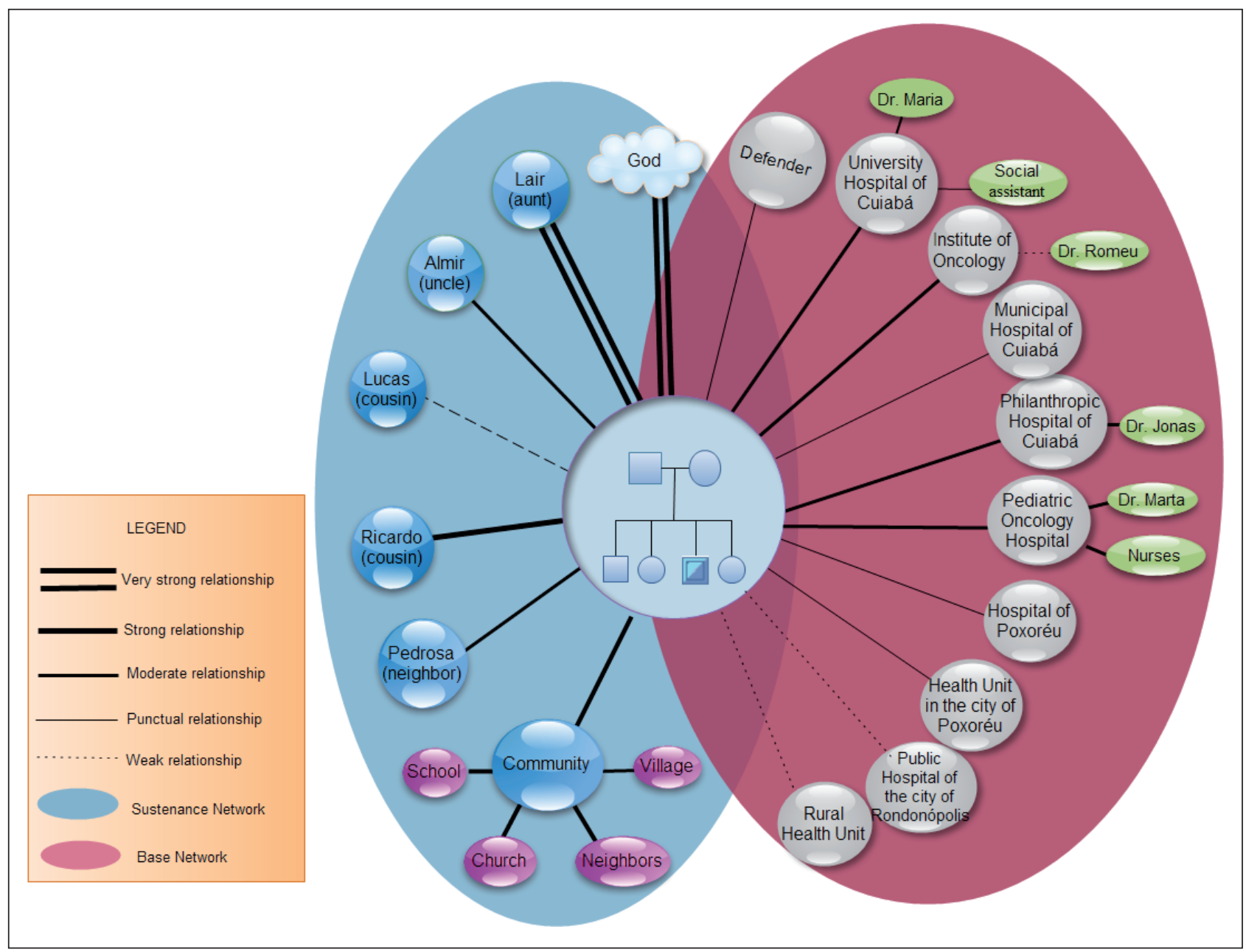

Figure 2 - Eco-map of a young man who experienced concomitant chronic conditions: kidney disease and cancer, and his family. Cuiabá-MT, 2015.

The base network (Figure 2) is the one participating in the most constant care in the life of the ill person, based on affection. ${ }^{10}$ It "consists of people who are the closest, such as family members and friends, who are present both regarding achievement of resources and in search for ensuring them to provide care, in sufficient quantity and quality in different health situations experienced over time". 27:392

Thus, although Marco's family is the main caregiver, it does not provide care alone because, in the face of many difficulties he faced, among them the precariousness of health care, the young man and his family have the support of friends, neighbors and members of the rural community mediating health care. These people extend the potential of family care as they allow the development of means to face the many difficulties of the disease process and treatment. ${ }^{28}$

As evidenced in a study that addressed the search for care of a person with a chronic disease, diabetes mellitus, ${ }^{29}$ it was observed that the young man and his family also gave their own logic to their search, intensely mobilizing people of their own social context for getting responses for their needs more effectively. From these networks that were created, the family received diverse help, as shown in the statements: [...] he gathered the commu- 
nity, farmers, family, everyone! (Rita). [...] Then they did the auction in the church right up there, everyone gathered! At that time, they got about eight thousand for Marco, right? [...] Then they decided to make an auction too. Teachers and students got together and did an auction too, they got about eleven thousand! It was a very big help (Olavo).

The community, including church, friends and school members, organized two auctions to raise funds to pay the young man's tests that needed to be performed with an agility that public health services could not offer. In a casual conversation with one of the organizers of the event, he pointed out that the community was moved by the story of the boy and mobilized efforts to provide significant financial assistance to the family.

Throughout his illness, he could rely on faith to minimize his suffering and, through it, he sought the strength to face the difficulties of illness: I always believed in God, you know, I always had faith that I'm cured [...] and I didn't mind, [...] I never put in my mind that it [the cancer] was a problem for me (Marco).

This same faith was shared by community members, who used it to support Marco's family: and when he was with him over there [in Cuiaba for treatment] they met here and prayed the rosary [referring to the community] (Rita).

Religiosity is associated with active coping strategies, planning, positive reinterpretation and instrumental social and emotional support. ${ }^{30}$ It is an important support in situations that are considered difficult, such as the treatment of cancer and kidney disease, permeated with stressful events. In the situation of Marco and his family, sharing of religiosity becomes even a mode of care, intrinsically amalgamated to their life in the community.

Regarding the support network for care, ${ }^{10}$ it is present in the constitution of "relationships that are less close and of lower emotional density, more punctually driven, but not less important for ensuring care maintenance, particularly that outside the family scope". 27:393 In addition, people and/or institutions, health professionals, as well as other services that were present on the way through treatment, are also part of this network.

In the case of Marco and his family, it consisted of 11 health institutions of different levels of care, sought during the course of his disease, namely: a rural health unit, located inside city A; a family health unit and a hospital in city A; a public hospital in city $\mathrm{C}$; a pediatric cancer hospital, a philanthropic hospital, a municipal hospital, an institute of oncology, a university hospital, located in Cuiabá. Also, the State Public Defender was contacted to guarantee their right to health, as shown in Figure 2.

These institutions have contributed to Marco's care, especially in periods of acute exacerbation of his disease. In the public hospital of City C, for example, he made some consultations to resolve the pain he felt in his ear, before the diagnosis of cancer, having a weak bond with the institution. The relationship was even weaker with the rural health unit, because when he searched for care there, it was closed.

In his childhood, since the onset of pain due to kidney problems, his parents took him to the health unit of city A, which referred him to the hospital in city A. If there was no relief of his pain, he was sent to the municipal hospital of the city of Cuiabá, staying in the hospital for three days, showing the pilgrimage required to get an answer to his problems. This hospital, in its turn, referred him to the philanthropic hospital in Cuiabá, which performed the first kidney surgery. The bond established with this institution was moderate, since he remained accompanied in this place during treatment for kidney disease, and then underwent another surgery.

Years later, when he began to feel pain in the ear, he was referred to the hospital in city C. As his father did not trust the medical procedures that were taken there, he went to the university hospital in Cuiabá, from where it was referred to an otolaryngologist who detected a lymphoma. The specialist referred him to an oncology hospital and there the young man started his treatment for the lymphoma. We observed a moderate relationship with this institution, as well as with the professionals who worked there because, at various times, the young man had to seek resolution to his health problems. Once, it was necessary to start a process through the courts to get one of Marco's chemotherapy drugs, because it was not offered by the public health system. The judicial order was soon granted, but the drug took six months to be delivered by the state.

When he was 20, Marco was treated by an oncologist from the Institute of Oncology, and though he mentioned being cured of cancer after treatment, he continued to be monitored in the unit because of the possibility of tumor recurrence, indicating a moderate relationship with the institution.

The absence of a strong bond of the young man and his family in relation to institutions and health professionals is highlighted, and this finding is even more remarkable if we consider the long-term aspect of his illness. It is possible to note that, in the institu- 
tions to which there was a moderate bond, this bond was with specific health professionals who most directly contributed to his care, being also cited by members of the family interviewed (Figure 2).

Bond is considered a relationship grounded in healthcare professional accountability, and in the assistance effectiveness. It implies interdependence of commitment of healthcare professionals to the ill person, and vice-versa. ${ }^{31}$ In the experience of disease of this young man, which was marked by the simultaneity of two chronic diseases, the support network activated by the family, mainly composed of institutions and healthcare professionals, proved to be underpowered to ensure the integrated care to both diseases, in a continuing and prolonged manner as required by law. What we realized is that the institutions 'get untied' after each intervention, and did not ensure the necessary permanence and continuity of professional care required by the adolescent's health situation, and the necessary longitudinality was not provided, which would ensure the necessary long-term reference of care. ${ }^{31}$

Thus, we concentrated on the punctual mode of action that is disconnected from the support network with the implicated, affective and continued form with which the base network participated in the experience of illness of Marco and his family.

\section{FINAL CONSIDERATIONS}

The present study was based on the use of two tools, the genogram and the eco-map, which allowed us to provide visibility and understanding of how the family of an ill young man who had concomitant diseases was organized for care, establishing relationships that enabled them to compose care nucleus and create networks that based and supported them in this process. It was possible to show how the family produces, searches and manages the intense, continuing and prolonged care required by Marco since his childhood and particularly during periods of simultaneity of the two diseases in adolescence. It was possible to show how punctual the responses to his health needs were given by the support network, formed mainly by services and healthcare professionals. In contrast, the strong support that the young man and his family had from people who made up his support network was evidenced, particularly from the members of the rural community, who significantly contributed to the relief of his suffering by providing various aids for his care.
There was not an early planning of this care, but it was constituted in the face of daily needs that the illness imposed, extended by the concomitance of diseases. This understanding is essential for health professionals, since organization logic of their practices have care protocols for the disease as central, with little consideration to the broader needs of the ill person and his family, and how they are affected by the disease, requiring frequent reorganizations in their daily lives.

The use of the genogram and the eco-map by health professionals, especially by nurses stood out, which allowed them to know how the family is organized for care, the resources and networks on which they relied on in the experience of a chronic disease, when their potential of care needs to be renewed due to the permanence and intensity of care required by the ill one.

\section{REFERENCES}

1. Musquim CA. Experiência de cuidado pelo homem na vivência familiar de adoecimento crônico [dissertação]. Cuiabá (MT): Universidade Federal de Mato Grosso, Programa de Pós-Graduação em Enfermagem; 2013.

2. Mufato LF, Araújo LFS, Bellato R, Nepomuceno MAS. (Re)Organização no cotidiano familiar devido às repercussões da condição crônica por câncer. Cienc Cuid Saude. 2012 Jan-Mar; 11(1):89-97.

3. World Health Organization (WHO). The adolescent with a chronic condition: epidemiology, developmental issues and health care provision. Switzerland: WHO; 2007.

4. Buchbinde M, Longhofer J, McCue K. Family routines and rituals when a parent has cancer. Fam Syst Health. 2009; 27(3):213-27.

5. Almeida KBB, Araújo LFS, Bellato R. Family caregiving in chronic illness: a young person's experience. Rev Min Enferm. 2014 Jul-Set; 18(3):724-32.

6. Nóbrega RD, Collet N, Gomes IP, Holanda ER, Araújo YB. Criança em idade escolar hospitalizada: significado da condição crônica. Texto Contexto Enferm. 2010 Jul-Set; 19(3):425-33.

7. Herge WM, Streisand R, Chen R, Holmes C, Kumar A, Mackey ER. Family and youth factors associated with health beliefs and health outcomes in youth with type 1 diabetes. J Pediatr Psychol [Internet]. 2012 [cited 2015 Ago 06]; 37(9):. Available from: http://www. ncbi.nlm.nih.gov/pubmed/22661616

8. Rostami S, Parsa-Yekta Z, Najafi-Ghezeljeh T, Vanaki Z, Zarea K. Self-perception in Iranian adolescents with diabetes: a qualitative study. J Diabetes Metab Disord [Internet]. 2015 [cited 2015 Ago 06]; 36(14):. Available from: http://www.ncbi.nlm.nih.gov/pmc/articles/ PMC4462089/pdf/40200_2015_Article_163.pdf 
9. Araújo LFS, Bellato R, Hiller M. Itinerários terapêuticos de famílias e redes para o cuidado na condição crônica: algumas experiências. In: Pinheiro R, Martins PH, organizador. Avaliação em saúde na perspectiva do usuário: uma abordagem multicêntrica. Rio de Janeiro (RJ): ABRASCO; 2009. p. 203.

10. Bellato R, Araújo LFS, Faria AP, Costa ALRC, Maruyama SAT. Itinerário terapêutico de famílias e redes para o cuidado na condição crônica: alguns pressupostos. In: Pinheiro R, Martins PH, organizador. Avaliação em saúde na perspectiva do usuário: uma abordagem multicêntrica. Rio de Janeiro (RJ): ABRASCO; 2009. p.187-94.

11. Van Velsen J. A análise situacional e o método de estudo de caso detalhado. In: Feldman-Bianco B, organizador. Antropologia das sociedades contemporâneas: métodos. $2^{\mathrm{a}}$ ed. São Paulo: UNESP; 2010.

12. Dolina JV, Bellato R, Araújo LFS. O adoecer e morrer de mulher jovem com câncer de mama. Ciênc. saúde coletiva [Internet]. 2013 [cited 2015 Jan 25]; 18(9). Available from: http://www.scielo.br/pdf/csc/ v18n9/v18n9a22.pdf

13. Dolina JV, Bellato R, Araújo LFS. Distinct temporalities in the breast cancer disease process. Rev Esc Enferm USP [Internet]. 2014 [cited 2015 Ago 12]; 48(2):. Available from: http:/ / www.scielo.br/pdf/reeusp/ v48nspe2/0080-6234-reeusp-48-nspe2-00073.pdf

14. Bellato R, Araújo LFS, Faria APS, Santos EJF, Castro P, Souza SPS, et al. A história de vida focal e suas potencialidades na pesquisa em saúde e em enfermagem. Rev Eletr Enf [Internet]. 2008. [cited 2016 Abr 2016]; 10(3): 849-56. Available from: http:/ / www. fen.ufg.br/fen_revista/v10/n3/pdf/v10n3a32.pdf

15. Mariotto M, Araújo LFS, Bellato R, Dolina JV. Emprego do genograma na compreensão dos rearranjos familiares para cuidar no adoecer e morrer por câncer. Cad Ciênc Saúde [Internet]. 2013 [cited 2015 Ago 06]; 4(3):. Available from: http://issuu. com/faculdadessantoagostinho/docs/cadernos_de_ saude_v3_n4_2013_site

16. Minayo MCS. O desafio do conhecimento: pesquisa qualitativa em saúde. 12a ed. São Paulo: Hucitec; 2010.

17. Costa RP. Representação gráfica de famílias com recurso ao Genopro®: (re)descobrir o genograma familiar no contexto da investigação qualitativa. Indagatio Didactica [Internet]. 2013 [cited 2015 Ago 06]; 5(2):. Available from: http:/ / revistas.ua.pt/index. php/ID/article/viewFile/2486/2354

18. Correia EC, Martins GT. Genograma: um instrumento de saúde mental. Rev das Faculdades Santa Cruz [Internet]. 2009 [cited 2015 Ago 07] 7(2). Available from: http://www.santacruz.br/v3/revistaacademica/13/ cap3.pdf

19. Nascimento LC, Dantas IRO, Andrade RD, Mello DF. Genogram and ecomap: brazilian nursing contributions. Texto Contexto Enferm [Internet]. 2014 Jan-Mar cited 2015 Ago 07]; 23(1):211-20. Available from: http:/ / www.scielo.br/scielo.php?script=sci_ arttext\&pid=S0104-07072014000100211

20. Wendt NC, Crepaldi MA. A utilização do genograma como instrumento de coleta de dados na pesquisa qualitativa. Psicol Reflex Crit. 2008; 21(2):302-10.

21. Leonidas C, Santos MA. Family relations in eating disorders: the Genogram as instrument of assessment. Ciênc Saúde Coletiva [Internet]. 2015 [cited 2015 Jan 06]; 20(5):. Available from: http://www.scielo.br/ pdf/csc/v20n5/1413-8123-csc-20-05-01435.pdf

22. Agostinho M. Ecomapa. Dossier família. Rev Port Clin Geral [Internet]. 2007 [cited 2015 Ago 07]; 23:327-30. Available from: http:/ / eventos.fecam.org. br/arquivosbd/paginas/1/0.307825001366390062_ ecomapa.pdf

23. Corrêa GHLST, Bellato R, Araujo LFS, Hiller M. Itinerário terapêutico de idosa em sofrimento psíquico e família. Cienc Cuid Saúde [Internet]. 2011 [cited 2015 Jan 25]; 10(2):. Available from: http:/ / periodicos. uem.br/ojs/index.php/CiencCuidSaude/article/ view/10462/pdf

24. Bellato R, Araújo LFS, Mufato LF, Musquim CA. Mediação e mediadores nos itinerários terapêuticos de pessoas e famílias em Mato Grosso. In: Pinheiro R, Martins PH, organizador. Usuários, redes sociais, mediações e integralidade em saúde. Rio de Janeiro: UERJ/IMS/LAPPIS; 2011. p.177-84.

25. Gomes GC, Oliveira PK. Vivências da família no hospital durante a internação da criança. Rev Gaúcha Enferm [Internet]. 2012 [cited 2015 Jan 20]; 33(4):. Available from: http://seer.ufrgs. br / RevistaGauchadeEnfermagem / article / view/16430/23967

26. Hiller M, Bellato R, Araújo LFS. Cuidado familiar à idosa em condição crônica por sofrimento psíquico. Esc Anna Nery. 2011 Jul-Set; 15(3):542-9.

27. Bellato R, Araújo LFS, Dolina JV, Musquim CA, Corrêa GHLS. O cuidado familiar na situação crônica de adoecimento. In: Anais do $4^{\circ}$ Congresso IberoAmericano em Investigação Qualitativa, 2015 Ago 5-7; Aracajú: Investigação Qualitativa na Saúde 2015. p.393-8.

28. Silva AH, Bellato R, Araújo LFS. Cotidiano da família que experiência a condição crônica por anemia falciforme. Rev Eletr Enf [Internet]. 2013 [cited 2015 Jan 24]; 15(2):. Available from: http://dx.doi. org/10.5216/ree.v15i2.17687

29. Thaines GHLS, Bellato R, Faria APS, Araujo LFS. A busca por cuidado empreendida por usuário com diabetes mellitus: um convite à reflexão sobre a integralidade em saúde. Texto Contexto Enferm. 2009; 18(1):57-66.

30. Murakami R, Campos CJG. Religião e saúde mental: desafio de integrar a religiosidade ao cuidado com o paciente. Rev Bras Enferm [Internet]. 2012 [cited 2015 Fev 15]; 65(2):. Available from: http:/ / www.scielo.br/ pdf/reben/v65n2/v65n2a24.pdf 
31. Soares JL, Araújo LFS, Bellato R, Corrêa GHLS. Considerations about the health tie in the trajectory of search for elderly and the family care. Rev Pesqui Cuid
Fundam. [Internet]. 2013 [cited Fev 15]; 5(4):. Available from: http://www.seer.unirio.br/index.php/cuidadofundamental/article/view/2012/pdf_934 